dication is not given directly by the words

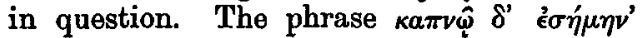
ă $\sigma \tau v$ is complete in itself and involves no 'singular ellipse.' Cf. also the absolute use

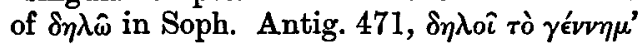

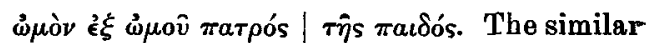

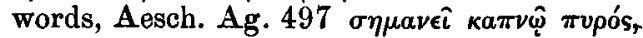
seem to me to support this interpretation.

A. W. MaIr.

\title{
CHARLES LAMB ALSO AMONG THE PROPHETS.
}

Is the twentieth volume (Berlin, Schwetschke, 1901) of the Theologischer Jahresbericht, p. 178 , is a curious proof that bibliographical industry may cast its net too wide. Under the heading 'Israelitische Religionsgeschichte' I find: 'Lamb, C., Essays of
Elia. 2nd series. N.Y. Scribner (London, Maemillan).' I gladly bear witness to the general accuracy and astonishing diligence of the contributors to this serial, which stands at the head of its department.

JoHN E. B. MaYoR.

\section{ARCHAEOLOGY.}

\section{THE TITULI ASIAE MINORIS.}

THE appearance of the first volume of this splendid publication of the Vienna Academy marks a considerable advance in the series of Corpora of ancient inscriptions on which a whole army of epigraphists are engaged. It is edited by Prof. Ernst Kalinka, and contains the Tituli Lycice lingua Lycia conscripti, with the addition of two stray examples, one of Carian, the other of Aramaic-the only inscriptions of their kind from this part of the peninsula. The Corpus is to contain all inscriptions, in whatever ancient language, with the exception of the Monumentum Ancyranum and Diocletian's Edict; since these documents have already been well edited, and have no special local significance, they will not be included unless fresh circumstances make their revision necessary. We are to have the inscriptions of each site collected together, whatever their language -an arrangement which will considerably lighten the physical portion of the labours of historian and topographer. The first volume forms an exception to this rule, since the Greek inscriptions of Lycia are severed from the native ones, except in cases where the two languages figure on the same stone. The reason for making this exception is as excellent as it is obvious ; the main object of the student of Lycian inscriptions at present is a philological one, and what he requires more than anything else is a convenient collection of all known texts. The vast majority of Greek texts from these parts belong to a later date, and their inclusion would only hamper the 'Lyciologist.' Indeed, the hanorary decree of the demos of Telmessus (No. 5) cut on a tomb already provided centuries before with a suitable sepulchral inscription, might very well have been excluded.

The recent publications of the Vienna Academy and the Austrian Archaeológical Institute have taught us what to expect in the way of printing and illustration. In many of the epigraphic collections which we have to use, anything in the way of a facsimile comes like an oasis amid a desert of type. Here every inscription, where the original is not lost or inaccessible, is reproduced in facsimile, and there is a considerable use of blocks showing the construction of some of the more important inscribed monuments. A brief, but carefully written introduction, full indices (arranged both by initials and by terminals), and a revision of Kiepert's map by Dr. Rudolf Heberdey, make the equipment of the book admirably complete.

The introduction contains, among other things, a good summary of what we know about the Lycian accidence-it does not fill two pages! -and an interesting paragraph on the ethnological relationship of the Lycians. The editor argues that nearly all 